\title{
ANALYSIS OF FORENSIC AUTOPSIES IN YEAR 2018 AT FORENSIC MEDICINE DEPARTMENT, FAISALABAD MEDICAL UNIVERSITY, FAISALABAD.
}

\footnotetext{
1. $4^{\text {th }}$ Year MBBS

Faisalabad Medical University, Faisalabad.

2. $3^{\text {rd }}$ Year MBBS

Faisalabad Medical University,

Faisalabad.

3. $3^{\text {rd }}$ Year MBBS

Faisalabad Medical University, Faisalabad.

4. MBBS, MCPS (Forensic Medicine)

Assistant Professor/Head Forensic

Medicine

Faisalabad Medical University,

Faisalabad.
}

Correspondence Address:

Dr. Muhammad Qasim

Faisalabad Medical University,

Faisalabad.

qasim1293@yahoo.com

Article received on:

19/12/2019

Accepted for publication:

$15 / 04 / 2020$

\begin{abstract}
Muhammad Qasim ${ }^{1}$, Muhammad Sharjeel Khalid ${ }^{2}$, Danyal Amjad ${ }^{3}$, Mobin Inam Pal ${ }^{4}$
\end{abstract}
\begin{abstract}
Objectives: The study was aimed to audit autopsies in the year 2018 and promoting statistical approach in Forensic Medicine. Also to study the gender based distribution of cases and study shifting trends in weapon of offence. Study Design: Retrospective Study. Setting: Post Mortem Unit of the Department of Forensic Medicine \& Toxicology, Faisalabad Medical University, Faisalabad. Period: From $1^{\text {st }}$ January, 2018 to $31^{\text {st }}$ December, 2018. Material \& Methods: Autopsy was performed on 248 cases reported to Post Mortem Unit. Study Material was collected from the Post Mortem Unit of Allied Hospital and DHQ Hospital Faisalabad which are referral tertiary care teaching hospitals affiliated with Faisalabad Medical University, Faisalabad. Results: Out of a total 248 autopsies conducted $178(71.77 \%)$ were males and 70 (28.23\%) were females. The male to female ratio was 2.54:1. Most used weapon of offence was Firearm. Followed by firearm the second major cause of death was road traffic accidents which were followed by Asphyxia (12.9\% of total autopsies). Conclusion: Ban on illegal possession of Firearms - educational lectures to Public and steps to raise the literacy rate along with the improvement of socioeconomic status of the society. Preventive-strategy to create an awareness of safe traveling practices especially among the groups at high risk.
\end{abstract}

Key words: $\quad$ Asphyxia, Audit, Autopsy, Firearms, RTA.

Article Citation: Qasim M, Khalid MS, Amjad D, Pal MI. Statistical analysis of forensic autopsies conducted in year 2018 in forensic medicine department, FMU/ AHF, Faisalabad. Professional Med J 2020; 27(10):2199-2202.

DOI: 10.29309/TPMJ/2020.27.10.4432

\section{INTRODUCTION}

Autopsy (post-mortem examination, necropsy) is a methodical, current medical procedure performed in a surgical manner, through which we systematically check tissues and organs of a human body after death, aiming at defining the cause of death and of mechanisms involved. ${ }^{1}$

Autopsy has to be conducted by a well trained and experienced doctor in the field of Forensic Medicine / Forensic Pathology; in all cases of sudden, suspicious \& unexpected deaths especially those resulting due to violence. While proceeding to the scene of crime, the investigating team should include Forensic Experts or the doctors having adequate knowledge of Forensic Medicine, so that important scene evidences may be collected, evaluated and preserved properly to fit the investigative puzzle. The autopsies eliminate suspicion, provide reassurance to families, substitute facts for conjecture, construct a better defense and improve the quality of care.
Though medical conventions and legal systems vary considerably from country to country, the autopsy can be divided into clinical or academic and forensic or medico legal autopsies.

There is a need of critical analysis of every medico legal procedure conducted in Forensic Medicine. The focal point of these procedures could only be identified when we have properly recorded and evaluated this data time and again.

Medico legal or forensic autopsy is performed on the instructions of legal authority compelled for investigations of impetuous, apprehensive, ambiguous, anomalous, belligerent or criminal deaths. In most systems the permission of relatives is not required as the objective of the legal investigation would be thwarted. Medico legal autopsy is effectual for the furtherance of justice in the courts by determining exact cause, manner \& mechanism of death. ${ }^{2}$ 
"A surgical operation is attended with pain and is for the benefit of the Individual, an autopsy is free from pain; is for the benefit of humanity. Paul. $\mathrm{H}$. Brussara".

\section{OBJECTIVES}

To audit autopsies in Year 2018 and to encourage statistical approach in the subject of Forensic Medicine. The need to analyze the gender based distribution of cases. Scrutinize the most used weapon of offence.

\section{MATERIAL \& METHODS}

It is a Retrospective study. The Study Material was collected from the Post Mortem Unit of Allied Hospital and DHQ Hospital Faisalabad which are referral tertiary care teaching hospitals affiliated with Faisalabad Medical University, Fsd. The study was conducted on victims of Firearm injuries, RTA, Asphyxia, Sharp-edged and blunt weapons, Electrocution, Railway accidents, burning and drowning that were reported to this center for autopsy. The study was conducted from 1st Jan 2018 to $31^{\text {st }}$ Dec 2018. The sample size was 248 autopsy cases upon which autopsy was performed.

For all study variables regarding mean percentages and frequencies was done using EXCEL software.

\section{RESULTS}

Out of a total 248 autopsies conducted in 2018 $178(71.77 \%)$ were males and $70(28.23 \%)$ were females. The male to female ratio was $2.54: 1$ as shown in pie chart (Figure-1).

Firearm was on the top causing $31.05 \%$ deaths in total. Out of total firearm victims male's fraction was $81.82 \%$ and female's fraction was $18.18 \%$. (Figure-2 weapon of offence).

Followed by firearm were road traffic accidents which accounts for $19.76 \%$ deaths, which was followed by Asphyxia (12.9\% of total autopsies).

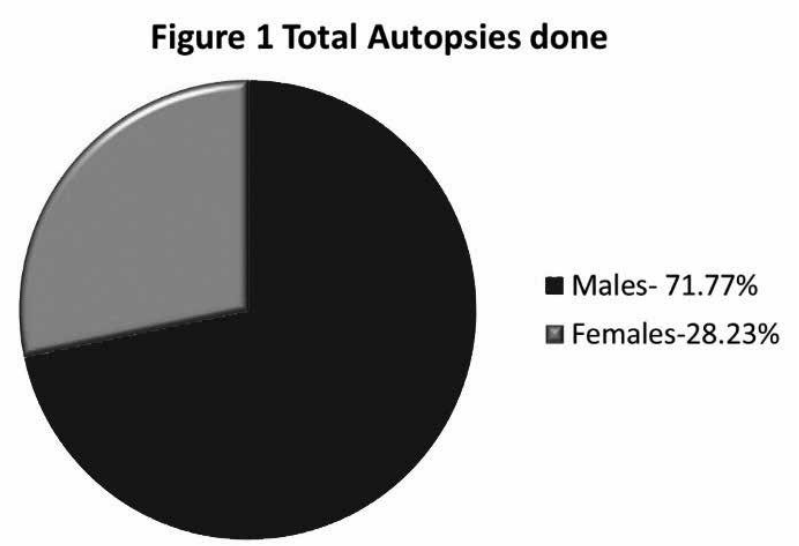

Figure-1. Total Autopsies done

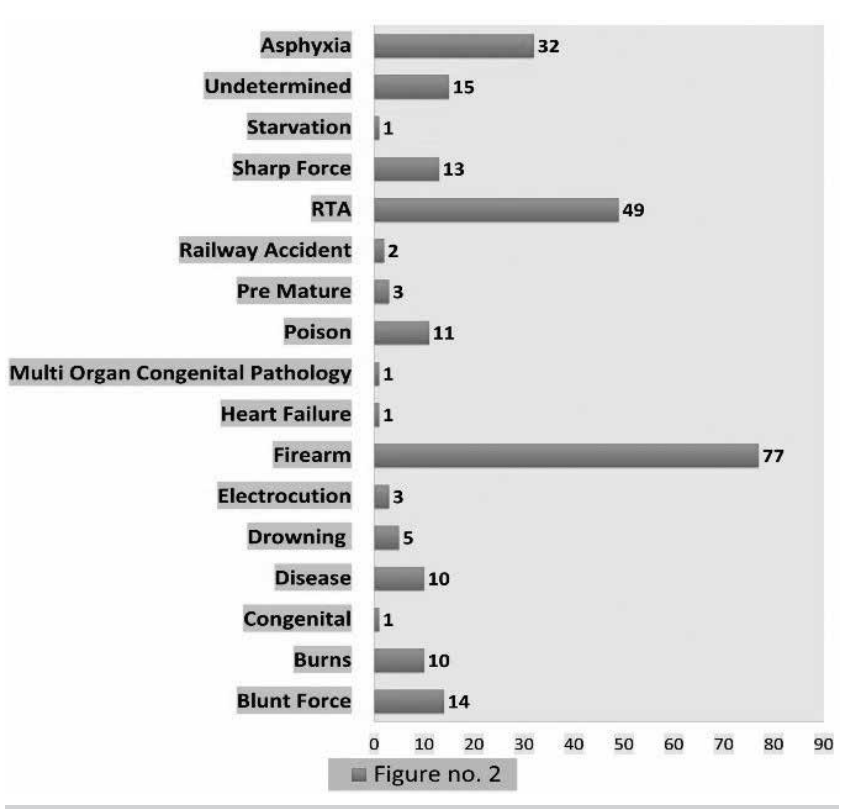

Figure-2.

\section{DISCUSSION}

Out of a total 248 autopsies conducted 178 $(71.77 \%)$ were males and $70(28.23 \%)$ were females. The male to female ratio was $2.54: 1$. This showed us that more autopsies were conducted on males than females. A similar trend was observed in the study of Pakistan ${ }^{3}$ and Nigeria. ${ }^{4}$ Males are more prone to life threatening conditions as compared to females and fall prey to criminal offences. Owing to the social gnomes and conventional trends males are mostly burdened with responsibility of earning livelihood for their families unlike females, majority of who are house wives in our society. 
As far as the weapon of offence was concerned, our study revealed that firearm was on the top causing $31.05 \%$ deaths in total.

This trend was similar to the studies conducted by Nadeem $S^{7}$ and Qasim AP. ${ }^{3}$ The approach to firearm weapons has been illuminated as "universal" perilous factor. ${ }^{8}$ The use of firearms as weapons of onslaught outside conflict or police settings advances to escalate. Firearms are comparatively accessible, whether in administration where their possessor ship and appliance is conceded or not. ${ }^{9}$ Out of this $31.05 \%$; males were $81.82 \%$ and females $18.18 \%$. These findings are in line with other local studies conducted in different cities of Pakistan. ${ }^{10,11,12}$ In our multidisciplinary and interprofessional collaborative society, general family systems and community settings, majority of victims of aggressiveness among people, exposure to violence and easy availability of guns and firearms, were males.

Followed by firearm were road traffic accidents which accounted for $19.76 \%$ deaths. About 1.25 million people die every year as a result of road traffic crashes. ${ }^{13}$ According to the report of 2009, 25.3 deaths per 100,000 occurred due to road traffic injuries in Pakistan being much higher than international proportions. ${ }^{14}$

This showed one of the most commonly acknowledged but most neglected anomaly of our society which requires urgent and immediate interventions which is lack of driving safety rules on behalf of both drivers and society as a whole and failure of government to implement the rules by modifying the old rancid system.

On third number weapon of offence was Asphyxia which accounted for $12.9 \%$ of total autopsies conducted.

\section{CONCLUSION}

The prevalence of firearm mortality is high. Collaboration is critical to bring about the meaningful changes to reduce the burden of firearm injuries and death on families, communities, and the society. Steps should be taken to minimize the use of firearm, the most lethal weapon by effective implementation of law and ban on illegal possession. Educational lectures to public and steps to raise the literacy rate along with the improvement of socioeconomic status of the society.

This requires strict laws and regulations of sale, purchase and possession of firearms with heavy fine and imprisonment in case of violation. Fatalities due to road traffic can be reduced by adopting a comprehensive preventive strategy to create an awareness of safe traveling practices especially among the groups at high risk. Recurrent increasing fines on persons with "casual attitudes", non-compliers of traffic rules \& road safety measures, users of cell phones during driving.

\section{ACKNOWLEDGEMENT}

Associate Professor Dr. Khurram Sohail Raja Head of Forensic Medicine department

Aziz Fatima Medical \& Dental college,Faisalabad (Ex-HOD, Punjab Medical College,Faisalabad) Professor Dr. Zahid Masood

Head of Community Medicine Department University Medical \& Dental College,Faisalabad We are sincerely thankful to them for their support \& guidance.

\section{Copyright@ 15 Apr, 2020.}

\section{REFERENCES}

1. Morar, S., Perju-Dumbrava, M., Cristian, A.: Aspecteeticeşilegale ale utilizăriicadavruluiumanînscop didactic şiştiințific (Ethical and legal aspects of the use of human body for didactic or scientific purposes). In: Revista Romana de Bioetica 2008, 6(4): 65-74.

2. Rautji R, Kumar A, Behera C. Attitudes of medical students towards medico legal/clinical autopsy. J Indian Acad Forensic Med. 2013; 35(4):358-61.

3. Qasim Ap, Awan ZA, Ansari AJ. Critical appraisal of autopsy work. APMC 2016; 10(4): 194-202.

4. Mandong BM, Manasseh AN, Ugwu BT. Medicolegal autopsies in North central Nigeria. East African medical journal. 2006;83(11):626-30.

5. Payne, Sarah, et al. "The social construction of gender and its influence on suicide: A review of literature". Journal of Men's Health 2007; 5(1):23-35. 
6. Moller-Leimkuhler, Anne Maria. "The gender gap in suicide and premature death or: Why are men so vulnerable?" European Archives of Psychiatry and Clinical Neuroscience 2003; 253(1):1-8.

7. Nadeem S, Qasim AP, Habiba U, Tariq F, Qasim JA. Audit of firearm autopsy cases in district Sahiwal. APMC 2017; 11(3):187-90.

8. Rawson B. Aiming for prevention: Medical and public health approaches to small arms, gun violence, and injury. Croat Med J 2002; 43(4):379-85.

9. Shepherd RS, Simpson's forensic medicine. CRC Press; 2003
10. Siddiqui BA, Saeed A, Masud U. Epidemiology of homicidal deaths in Sargodha Pakistan. Prof Med J, 2013; 20(5): 793-7.

11. Malik R, Chughtai BR, Khursheed R, Amanat M, Khan SP, Rizvi S. Pattern of unnatural deaths-an audit of autopsies. JRMC 2017; 21(1): 97-9.

12. Aziz F, Qasim AP, Khaliq S, Naheed K, Qasim JA. Spectrum of firearm related deaths in Multan city: Autopsy based study. APMC 201 8; 12(1):28-30.

13. WHO. (2015) Fact sheet No.358 October 2015.

14. (WHO) Global status report on road safety: Time for action. (On line). 2010. (Cited 2012 Feb28).URL: http:// whqlibdoc.whoint/publications/2009/9789241 563840eng.pdf.

\begin{tabular}{|c|c|c|c|}
\hline \multicolumn{4}{|c|}{ AUTHORSHIP AND CONTRIBUTION DECLARATION } \\
\hline Sr. \# & Author(s) Full Name & Contribution to the paper & Author(s) Signature \\
\hline 1 & Muhammad Qasim & $\begin{array}{l}\text { Co-author, Designing \& } \\
\text { Acquisition. }\end{array}$ & $\frac{\text { Mimgoin. }}{\text { sracivel }}$ \\
\hline 2 & M. Sharjeel Khalid & Co-author, Literature review. & $\begin{array}{l}\text { Sharjoed } \\
\text { khh a d }\end{array}$ \\
\hline 3 & Danyal Amjad & Data analysis. & Dampel \\
\hline 4 & Mobin Inam Pal & Proof reading & Fobitian. \\
\hline
\end{tabular}

